a tentative way at first for tailings assays, for which neither the cyanide nor iodide methods were suitable, nor, from the arsenic and manganese present, was the usual colorimetric method. It was later adopted for the assays on crude ore and concentrates, and its results have been uniformly satisfactory. In practice it takes about the same time as the iodide method, and while, for copper to the amount of 3 per cent. and upwards, it may not offer many advantages over the latter method, which cannot well be improved upon, it is more accurate than, and distinctly superior to, either the iodide or cyanide method for small or fractional percentages of copper.

LABURATORY OF THE SILVER LAKE MINES,

Silverton, Colo., April Ig, IgOz.

[CONTRIBUTION FROM THE LABORATORY OF THE BUREAU OF INTERNAL Revenue, U. S. Treasury DhPartment.]

\title{
THE INFLUENCE OF THE GROWTH OF MOLD UPON THE CHEMICAL COMPOSITION OF OLEOMAR. GARINE AND BUTTER.
}

By Charles A. Crampton.

Received April 12, 2902.

Havine occasion to pass through the ordinary course of analysis a number of samples of oleomargarine, which had been kept in glass-stoppered bottles for about two years, I was much surprised at the results obtained. The samples, about fifty in number, had a well-authenticated history of having been taken from different packages of the same shipment of oleomargarine, a shipment which was represented by a single sample taken at the time and examined in this laboratory, giving a normal Reichert-Meissl figure.

Instead of obtaining the usual figures from the fifty old samples, as would be expected, and a close agreement among themselves, the results varied greatly; and what was still more striking, the figures given by one determination-that of the refractive indexwere so low in some cases that the samples would have been classed as butter, if judged by this test alone, while others gave results normal for oleomargarine. Many of the samples were permeated with a growth of dark green mold, and on tabulating the results, it was soon seen that this was the cause of the differences, the 
greatest divergence being between the samples showing a strong growth of the parasitic plant, and those showing a little or none.

The samples were divided roughly into three classes, according to the apparent amount of mold present.

Unfortunately, the amount of material was very small in any of the samples, so the only determinations that could be carried out upon all were of the Reichert-Meissl figure and refractive index, but specific gravity, Valenta, and iodine values were obtained from a few samples in each class.

The average figures for each group are tabulated together, as follows :

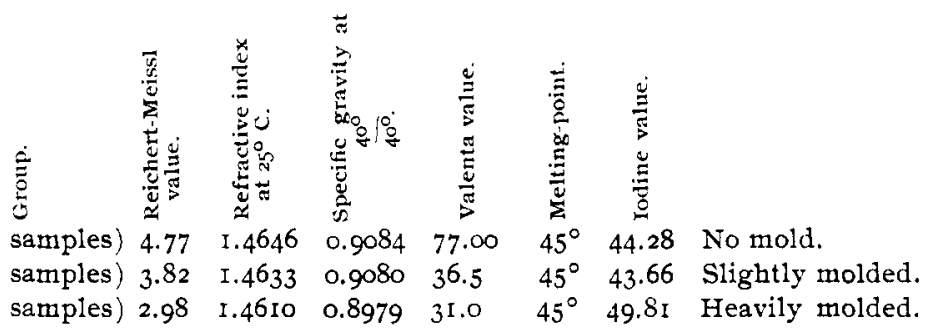

It will be seen that the molded fat gives a much lower average figure in all the constants than the fat free from fungus, with the single exception of the iodine value. The melting-point is the same in all. The original sample which represented the same material, and which had been kept in this laboratory since December, 1899 , was looked up and found to be apparently free from mold. It is not strictly comparable with the series of samples which were taken and preserved by parties other than internal revenue officers, but may fairly be presumed to approximate pretty closely the same material. Unfortunately but one determination, that of the Reichert-Meissl value, was made upon this sample at the time of its receipt in $\mathrm{I} 899$. It gave $\mathrm{R} . \mathrm{M} .=2.42$. An ample supply of material was still available which had no outward appearance of change, except that it had developed the tallowy smell incident to oleomargarine on long keeping.

Following are the results obtained: 
SERIAL, No. 5264 .

Specific gravity at $\frac{40^{\circ}}{40^{\circ}} \ldots \ldots \ldots \ldots \ldots \ldots \ldots \ldots .9 .9105$

Refractive index at $25^{\circ} \mathrm{C} \ldots \ldots \ldots \ldots \ldots \ldots \ldots .4647$

Reichert-Meissl value................. 4.86

Acid value (cc. normal alkali required for I00

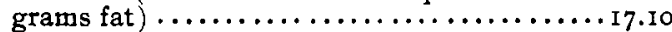

Hehner value .......................92.70

Valenta value......................68.o

Crismer value.$\ldots \ldots \ldots \ldots \ldots \ldots \ldots \ldots \ldots 6.3$

Iodine value $\ldots \ldots \ldots \ldots \ldots \ldots \ldots \ldots \ldots \ldots \ldots, 47.52$

Soluble fatty acids, per cent.............. I.04

These results correspond pretty closely with those obtained on the samples which showed no mold. Taken together, they indicate a very decided change in the values of the fat on long keeping, much more than has usually been recorded for butter-fat. The only determination made on the original, the Reichert-Meissl value, gives a considerable increase, and the other values have doubtless also changed, as some of them are quite abnormal for oleomargarine.

The figures obtained from the molded samples show a very wide divergence from the values given by those which have, presumably, been affected only by the action of the atmosphere. The Reichert-Meissl figure is much less, approaching the value ordinarily obtained from fresh oleomargarine, while the refractive index and Valenta value are about normal for butter. The specific gravity is very low, even lower than the normal figure for oleomargarine, and far below the specific gravity of the rancid samples. The iodine value shows a remarkable variation, which may be partly due to some difference in the original composition of the samples. Some of the latter gave a reaction for cottonseed oil, while others did not. The mold occurred in black spots on the fat, which penetrated entirely through the mass. The fat, on filtration, was of a reddish brown color, quite different from the color of the fat from the samples free from mold. In other respects (odor, taste, etc.) they did not differ greatly.

The samples, or rather residues of samples, had been kept in glass-stoppered wide-mouthed bottles. Several of the bottles were sent to Dr. Erwin F. Smith, of the Bureau of Plant Industry of the U. S. Department of Agriculture, who had kindly agreed to determine the character of the mold. He reported as follows upon the result of the examination: "All of the oleomargarine bottles furnished by you containing fungi have now been examined. The 
bulk of the black substance in each one is Comiothecium, probably an undescribed species. The species of this form-genus are not well differentiated, and are generally named after the substratum on which they are found. So far as I know there is no record of any such fungus on butter. Aspergillus occurs sparingly in three of the bottles, 5058, 5060 and 5061, but not in the fourth, 5014, and I cannot bring myself to believe that it occurs in sufficient quantity to have had any influence on the oleo."

Efforts to engraft this mold upon butter have, thus far, proved unsuccessful.

On making a search of the journals for recorded observations on the effect produced by mold on the composition of fats, I found the work of Hanus and Stocky: "Ueber die chemische Einwirkung der Schimmel-pilsen auf die Butter" (Zeitschrift Unt. Nahr. und Genussmittel, (I900), 3, 606).

They found that a sample of butter which had become covered with mold gave, on analysis, figures differing considerably from those originally obtained, more especially in acidity and volatile acids. They then made pure cultures of nine different species of mold and engrafted them upon butter of known composition. After three months had elapsed, they found very little change, which they explain upon the theory that the molds attack primarily the milk-sugar and protein substances in the butter, and first exert their effect upon the fat after these have been consumed. Finding that the species Mucor mucedo was best adapted to their purposes, on account of its mycelium penetrating deeper into the butter than the other varieties, they engrafted a culture upon butter of known composition, and allowed it to develop for a year, carrying along with it a blank sample of the same butter free from mold.

I have collected their results upon the three different samples into the following table:

\begin{tabular}{|c|c|c|c|}
\hline Chemical constants. & $\begin{array}{l}\text { Original } \\
\text { butter- } \\
\text { fat. }\end{array}$ & $\begin{array}{l}\text { Blank } \\
\text { control } \\
\text { sample. }\end{array}$ & $\begin{array}{l}\text { Molded } \\
\text { sample. }\end{array}$ \\
\hline \multicolumn{4}{|c|}{ Acid figure (cc. normal alkali required } \\
\hline for I00 grams fat) $\ldots \ldots \ldots \ldots \ldots \ldots$ & 5.10 & 107.0 & I09.5 \\
\hline Reichert-Meissl figure $\ldots \ldots \ldots \ldots \ldots$ & 27.17 & 24.3 & 24.0 \\
\hline nification figure $\ldots \ldots \ldots \ldots$ & .226 .00 & 222. I & 217.3 \\
\hline figure $\ldots \ldots \ldots \ldots \ldots \ldots$. & - $3^{6.20}$ & 34.1 & 35.2 \\
\hline s, per cent........... & 5.10 & 4.96 & 4.90 \\
\hline lar weight of volatile acids.. & - $93 \cdot 7^{\circ}$ & 102.1 & 102.2 \\
\hline olatile acids, per cent $\ldots \ldots \ldots \ldots$ & $\cdots$ & 0.40 & 0.55 \\
\hline cular weight of free volatile acids & ... & I 54.0 & I 44.0 \\
\hline Ether figure $\ldots \ldots \ldots \ldots \ldots \ldots \ldots$ & $\cdots$ & 162.2 & I 56.3 \\
\hline
\end{tabular}


From these results they reach the conclusion that the growth of molds has a decided effect upon the composition of butter-fat, splitting up the glycerides into fatty acids and glycerol, the latter serving as a nutrient to the molds; secondarily, the free fatty acids of lower molecular weight are either oxidized to higher acids, or are reduced, the presence of aldehyde-like bodies favoring the latter hypothesis.

The original butter used in the experiment was not sterilized, and the authors noted a considerable development of oidium, a different type of fungus growth, in the control sample, and also in the sample engrafted with mucor, both species growing together. They are, therefore, unable to say just how much of the change in composition is due to the growth of mucor, how much to oidium, and how much to the action of air and light solely.

Laxa ${ }^{1}$ found that the molds, Oidium, Penicillium, and Mucor, effect a hydrolysis of butter-fat, as do also the yeasts, though to a less extent. I have no access to the original paper.

The most recent and conclusive work upon the fat-destroying power of molds is that by Koenig, Spiechermann and Bremer, ${ }^{2}$ whose paper contains also a comprehensive review of the results recorded by other observers in this direction. They investigated the changes produced in the composition of cottonseed meal, along with other food and fodder materials, by various classes of microorganisms. They found a well-marked effect exerted upon the oil by both bacterial and fungous growths, under conditions favoring their development. I will quote here the more pertinent of their conclusions :

"8. Experiments with pure cultures of mycelium fungi obtained from cottonseed meal, and with other species grown upon sterilized cottonseed meal, and also upon artificially prepared nutrient material containing fat, have shown that the mycelium fungi are abundantly able to use as a source of carbohydrate both fats and the higher fatty acids (liquid and solid).

"9. Hand in hand with fat consumption goes always the splitting up of the fat, yet this reaction never extends to the entire body of fat present, and it varies in strength with different microorganisms.

1 Arch. Hyg., 41, 119; J. Soc. Chem. Ind., 21, 268 (1902).

2 Zeitschrift Unt. Nahr. und Genussmiltel $4,7^{21}$ and 769 (Igor). 
"I I. The fat is apparently, for the greater part, decomposed directly into carbonic acid and water."

The investigation showed that bacteria resisting a sterilization temperature of $100^{\circ}$ (so-called kochfester bacteria) were capable of bringing about the decomposition of fat, though not to the same extent as the fungous growths which are visible to the eye.

The results obtained by me strengthen the conclusions reached in the investigations outlined above, and have two important bearings:

First, a most practical bearing upon the interpretation of analytical results; and second, upon various unsolved problems of the constitution and metamorphosis of the glycerides. In regard to the first, the obvious lesson is that no reliance can be placed upon the ordinary constants used for the detection of foreign fats in butter when the sample in question has been invaded by the growth of mold. An apropos instance may perhaps be cited in a communication by $\mathrm{H}$. Droop Richmond in the British Food Journal, (1903) 3, 393. The writer discusses the anomalous results obtained in the analysis of Russian butter in certain important legal cases before the English courts. He is unable to account for the figures obtained, some of which point strongly towards adulteration; but he mentions, incidentally, the fact that his samples showed the growth of a mycelium fungus, and this probably affords the key to a solution of the entire matter.

A sample of butter, recently brought to this laboratory, showed a growth of mold upon a portion of its surface. A separation of the molded and unmolded portions was made, and the following values obtained. The identity of the mold was not established.

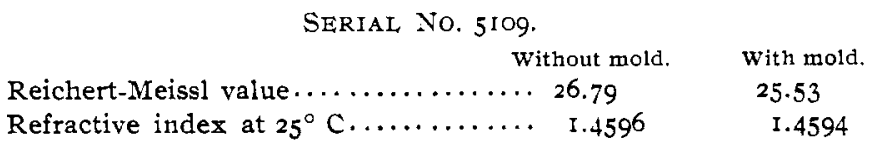

These results confirm the observations of Hanus and Stocky to the effect that the growth of mold in butter produces a slight but distinct decrease in the Reichert-Meissl value.

From another sample, however, I obtained values which showed a much more radical change in composition, and which are, so far as I am aware, the lowest in some respects ever reported from a genuine butter. This sample, Serial No. 5385, was received in 
February, I899, at which time it gave a Reichert-Meissl value of 29.92. For some reason it had not been thrown out, and when examined in March, I902, after remaining three years undisturbed in a tin can, it was found to be thoroughly permeated with a reddish brown mold.

This was examined by Dr. Smith, who reports it as Coniosporium sp.? He found also Penicillium sp.? in small quantity.

A fair quantity of the filtered fat was obtained, which was of a rather deep shade of orange-yellow. It gave the following values :

SERIAL No. $53^{85}$.

Specific gravity at $\frac{40^{\circ}}{40^{\circ}} \ldots \ldots \ldots \ldots \ldots \ldots \ldots \ldots, 0.897^{8}$

Refractive index at $25^{\circ} \mathrm{C} \ldots \ldots \ldots \ldots \ldots \ldots \ldots . .4578$

Reichert-Meissl value ................. I 3.09

Acid value (cc. normal alkali required for 100

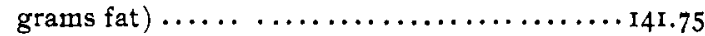

Iodine value $\ldots \ldots \ldots \ldots \ldots \ldots \ldots \ldots \ldots \ldots \ldots, 40.66$

The Reichert-Meissl value is less than half of the original; the refractive index is abnormal, being lower than that obtained from butter; and the specific gravity is rather lower than the usual "oleo" figure.

Returning to the results obtained from the oleomargarine which had been kept a long time, but which showed no apparent growth of mold, Serial No. 5264, the values approach figures normal for butter, as is also the case with those samples in the series which showed little mold. In further' confirmation of this, three other samples of oleomargarine were selected, none of which showed visible evidence of the presence of mold. These samples were received during the months of February and March, I899, and had consequently been kept (in tin cans) over three years. The following table gives the Reichert-Meissl values at the time of their receipt, and at the time of their re-examination; also the refractive indices, specific gravity, and acid values.

$\begin{array}{cccccc}\begin{array}{c}\text { Serial } \\ \text { No. }\end{array} & \begin{array}{c}\text { Reichert- } \\ \text { Meiss1 } \\ \text { value. }\end{array} & \begin{array}{c}\text { Reichert- } \\ \text { Meissl } \\ \text { value. }\end{array} & \begin{array}{c}\text { Refractive } \\ \text { index. }\end{array} & \begin{array}{c}\text { Specific } \\ \text { gtavity } \\ \text { at } \frac{40^{\circ}}{40^{\circ}}\end{array} & \begin{array}{c}\text { Acid value (cc. } \\ \text { normal alkali } \\ \text { required for } \\ \text { Ioo grams fat). }\end{array} \\ 5386 & 3.30 & 4.26 & 1.4639 & 0.9102 & 43.8 \\ 5387 & 1.76 & 5.60 & 1.4656 & 0.9159 & 5.0 \\ 5388 & 2.20 & 5.26 & 1.4679 & 0.9144 & 6 . \mathrm{I}\end{array}$


The changes brought about in the Reichert-Meissl values are fully as radical as in the other samples; the specific gravities also, while no comparison can be made owing to lack of data on the samples as originally received, have manifestly increased, as they are as high as butter normals.

From an analytical standpoint, these changes in composition are even more dangerous than those produced by the growth of a micro-organism like mold which is visible to the eye. That they are due entirely to the ordinary action of air and light cannot be believed, and this leads up to the consideration of the theoretical bearing of the results, particularly upon the nature of rancidity changes. Most of the authorities on fats and oils (Lewkowitsch, Wright, etc.) accept as conclusive the results of Ritzert ${ }^{1}$ who found that pure lard was not turned rancid by bacteria introduced into it, as they soon died; and that fat sterilized at $140^{\circ}$ became rancid on subsequent exposure to light and air.

I am not now in a position to oppose specifically the conclusion that a fat cannot become rancid without the presence of microorganisms, although I hope to be able soon to repeat the experiments of Ritzert upon this point. But I do not think there can be any room for doubt that the growth of micro-organisms plays a highly important rôle in the changes which occur in fats and oils under ordinary conditions of exposure. Even if it be granted that the breaking up of the glycerides may eventually take place merely from the presence of oxygen, it is certain that the change is greatly promoted and expedited by their development.

I think it may safely be asserted, for the edible fats, at least, where the presence of nitrogenous and other non-fatty matter affords a sprouting medium for such growth, that the greater part of the changes embraced under the general term "rancidity" is due to the action of micro-organisms, or to the enzymes resulting from their development. The most rational explanation of the results obtained on the samples of oleomargarine appears to me to be as follows: The glycerides, exposed to the cool damp air of the refrigerator, and in contact with the nitrogenous matter derived from the milk used in the process of manufacture, underwent a gradual decomposition, probably induced and promoted by bacterial growth, with the formation of the lower fatty acids. This pro-

1 Untersuchungen uberd. Ranzigwerden der. Fette, Inaug. Diss., Berlin, I8go. 
gressed to a very considerable degree, giving the high results obtained for volatile acids and specific gravity obtained from the samples which showed no mold. The germs of the Coniothecium fungus having gained access to the fat, or, more probably, having been contained in it originally, and their growth being started by the favorable conditions resulting from the splitting up of the glycerides, attacked the liberated fatty acids and glycerides, and consumed them in proportion to the growth. The growth of the fungus produced further decomposition and a further consumption of fatty acids, with a preferment for those of lower molecular weight, until the remaining mixture of fat and free acids gave the diminished values for volatile acids and specific gravity obtained from the molded samples.

Experiments are now in progress in this laboratory having the object of a more exact investigation of the changes brought about in fats by the growth of mold. This I hope to accomplish by growing pure cultures upon a large quantity of fat of known composition. As these experiments will necessarily require a long time for completion, I report the results set forth above as a preliminary paper.

My thanks are due to Mr. F. E. Simon and Mr. A. B. Adams of this laboratory, by whom the principal part of the analytical work was performed.

[CONTRIBUTION FROM THE JOHN HARRISON LABORATORY OF CHEMISTRY, No. 65.]

\section{AN ELECTROLYTIC STUDY OF PYRORACEMIC ACID. ${ }^{1}$}

BY GEORGE W. ROCKWEIL.

Received March 12, 1902.

WISHING to study the effect both of the oxidizing and reducing power of the electric current upon an organic body, aiming at the same time to fix the conditions so that other persons upon repeating the experiments might well expect to get similar results, I selected pure pyroracemic acid for my investigation.

The apparatus employed in the experiments consisted' of a beaker glass, a porous cup, which served as a septum for the separation of the anode and cathode liquids, and two platinum

1 From anthor's thesis for Ph.D. degree, 1900. 